\title{
Aplikasi Teori Newman: Bagaimana Kesalahan Siswa Dalam Menyelesaikan Permasalahan Geometri 3D?
}

\author{
Dhani N Hendrayanto ${ }^{1}$, Zainnur Wijayanto ${ }^{2}$, W Wahmad ${ }^{3}$, Sri A Widodo ${ }^{*}$ \\ 1,2,4Pendidikan Matematika, Universitas Sarjanawiyata Tamansiswa, Yogyakarta, Indonesia; \\ dhaninurhendrayanto11@gmail.com ${ }^{1}$; zainnurw@ustjogja.ac.id²; sriadi@ustjogja.ac.id $^{4 *}$ \\ ${ }^{3}$ SMP Negeri 10 Yogyakarta, Yogyakarta, Indonesia; wahmadspd@yahoo.ac.id ${ }^{3}$
}

Info Artikel: Dikirim: 14 Juni 2020 ; Direvisi: 21 September 2020; Diterima: 16 November 2020 Cara sitasi: Hendrayanto, D. N., Wijayanto, Z., Wahmad, W., \& Widodo, S. A. (2020). Aplikasi Teori Newman: Bagaimana Kesalahan Siswa Dalam Menyelesaikan Permasalahan Geometri 3D?. JNPM (Jurnal Nasional Pendidikan Matematika) 5(1), 94-108.

\begin{abstract}
Abstrak. Rendahnya prestasi belajar matematika salah satunya disebabkan oleh kesalahan siswa dalam menyelesaikan soal matematika. Banyak penelitian menyebutkan bahwa geometri merupakan materi yang sulit karena banyak prestasi dibawahkriteria ketuntasan minimal. Berkaitan dengan hal tersebut tujuan penelitian ini untuk mengetahui jenis-jenis kesalahan siswa dan penyebab terjadinya kesalahan siswa kelas VIII dalam menyelesaikan soal matematika geometri Bangun Ruang Sisi Datar bentuk soal cerita uraian berdasarkan teori Newman. Metode penelitian ini adalah deskriptif kualitatif. Partisipan penelitian ini berjumlah 2 orang yang dipilih berdasarkan alasan tertentu. Teknik pengumpulan data penelitian ini yaitu tes tertulis (tes diagnostik) dan wawancara. Teknik analisis data menggunakan teknik deskriptif. Temuan pada penelitian ini adalah siswa melakukan 4 jenis kesalahan berdasarkan teori Newman yakni kesalahan memahami makna suatu permasalahan, kesalahan transformasi, kesalahan keterampilan proses dan kesalahan penulisan jawaban akhir. Penyebab terjadinya kesalahan siswa diantaranya adalah keliru menafsirkan hal yang ditanyakan, tidak memahami konsep geometri.Dengan mengidentifikasi kesalahan siswa tersebut, guru terbantu dalam merencanakan pembelajaran yang tepat sehingga dapat mengantisipasi kesalahan yang sering dilakukan oleh siswa.
\end{abstract}

Kata Kunci: Teori Newman, Kesalahan, Masalah Geometri 3D.

Abstract. One of the low achievement in learning mathematics is caused by students' mistakes in solving math problems. Many studies have stated that geometry is a difficult material because many achievements are below the minimum completeness criteria. In connection with this, the purpose of this study was to determine the types of student errors and the causes of errors in class VIII students in solving mathematical problems in geometry. This research method is descriptive qualitative. The number of participants in this study was 2 people who were selected based on certain reasons. The research data collection techniques were written tests (diagnostic tests) and interviews. The data analysis technique used descriptive techniques. The findings in this study were that students made 4 types of errors based on Newman's theory, namely errors in understanding the meaning of a problem, mistakes in transformation, errors in processing skills and errors in writing the final answer. The causes of student errors include misinterpreting the things being asked, not understanding the concept of geometry. By identifying these student mistakes, the teacher is helped in planning the right lesson so that they can anticipate mistakes that are often made by students.

Keywords: Newman's theory, Errors, Problems of Geometry 3D. 


\section{Pendahuluan}

Memasuki era abad ke-21 ini, kondisi sumber daya manusia Indonesia terbilang masih sangat tidak kompetitif. Berdasarkan laporan terakhir catatan Human Development Report tahun 2019, peringkat HDI (Human Development Index) Indonesia atau kualitas sumber daya manusia Indonesia berada diperingkat 111 dari 189 negara (Morse \& Morse, 2019). Kemudian menurut hasil studi PISA tahun 2018 menunjukkan peringkat Indonesia pada kategori matematika yakni peringkat 73 dari 79 negara (Maskar, 2018; OECD, 2019; Sofiah, Suhartono, \& Hidayah, 2020). PISA merupakan penilaian internasional yang diselenggarakan tiga tahunan untuk menguji performa akademis anakanak sekolah usia 15 tahun dan penyelenggaraannya dilaksanakan oleh Organization for Economic Co-operation and Development (OECD, 2019; Sellar \& Lingard, 2014; Zulkardi, 2002). Konten matematika atau soal-soal matematika yang diujikan oleh PISA terdiri dari change and relationship (perubahan dan hubungan), space and shape (ruang dan bentuk), quantity (bilangan) serta uncertainly and data (ketidakpastian dan data) (Johar, 2012; Mansur, 2018; Setiawan, Dafik \& Lestari, 2014). Selain itu, hasil studi TIMSSterakhir tahun 2015 menunjukkan bahwa Indonesia berada diperingkat 44 dari 49 negara (Mullis, Martin, Foy \& Drucker, 2012, 2015; Watts, 2015). TIMSS merupakan penilaian internasional tentang pengetahuan matematika dan sains anak sekolah diseluruh dunia (Kartianom \& Retnawati, 2018; Kaune, CohorsFresenborg \& Nowinska, 2014; Mullis, Martin, Foy \& Hooper, 2018).

Melihat penilaian internasional melalui hasil studi Programme for International Student Assessmen (PISA)dan Third Mathematics and Science Study (TIMSS) terkait dengan mutu pendidikan dan prestasi peserta didik Indonesia khususnya di bidang matematika dapat dikatakan tergolong masih rendah karena termasuk dalam peringkat ke bawah. Untuk itu potensi peserta didik Indonesia sebagai generasi penerus bangsa harus selalu diperhatikan dan dikembangkan salah satunya yaitu melalui pendidikan matematika. Hal ini sependapat dengan sebuah penyataan bahwa sangat sulit atau tidak mungkin bagi sesorang untuk hidup di bagian bumi ini pada abad ke-20 tanpa sedikitpun memanfaatkan matematika (Siagian, 2016). Maka penguasaan materi matematika oleh siswa menjadi sebuah keharusan yang tidak bisa ditawar lagi didalam penataan nalar dan pengambilan keputusan diera persaingan global yang semakin kompetitif (Fuadi, Johar \& Munzir, 2016; Utami, Djatmika \& Sa'dijah, 2017; Widodo, 2013). Matematika sangat berkaitan erat dengan kehidupan sehari-sehari sehingga siswa akan mampu menerapkan matematika dalam konteks yang berguna bagi siswa baik dalam dunia kehidupannya ataupun dalam dunia kerja kelak, selain itu mempelajari matematika dapat membiasakan seseorang berpikir kritis, logis serta dapat 
meningkatkan daya kreativitasnya (Nurani \& Ramadhani, 2014; Sholihah \& Mahmudi, 2015; Siagian, 2016; Sutrimo, Kamid \& Saharudin, 2019). Oleh sebab itu matematika sangatlah penting dan perlu untuk dipelajari.

Berdasarkan wawancara peneliti dengan guru mata pelajaran matematika kelas VIII SMP N 10 Yogyakarta, guru menyampaikan bahwa prestasi belajar siswa masih kurang optimal pada matematika khususnya pada materi geometri. Hal ini ditunjukkan dengan nilai ulangan harian siswa pada materi geometri masih banyak siswa kelas VIII yang belum mencapai nilai Kriteria Ketuntasan Minimal (KKM) sekolah yakni 75. Guru menyampaikan bahwa masih banyak ditemukan siswa melakukan kesalahandalam menyelesaikan soal matematika geometri sehingga prestasi belajar siswa pada materi-materi matematika geometri masih kurang optimal, salah satunya yaitu pada sub materi matematika geometri yakni Bangun Ruang Sisi Datar.

Kondisi tersebut sejalan dengan observasi yang dilakukan Pangesti \& Retnowati (2017), Yoselin, Kartono \&Soedjoko (2016) dan Yuliyanto \& Jailani (2014) pada penelitian sebelumnya yang menyatakan bahwa kemampuan siswa dalam menyelesaikan soal geometri masih berada di bawah KKM. Hasil

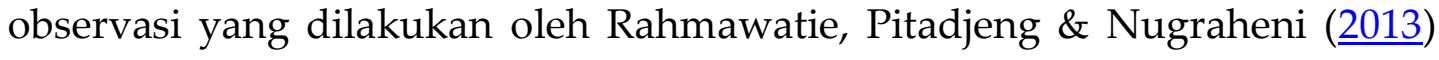
menunjukkan bahwa kemampuan siswa kelas IV SDN Purwoyoso 01 dalam menyelesaikan soal geometri hanya 15 siswa yang mencapai KKM dari 36 siswa. Begitupula hasil Ujian Nasional di SMP Negeri 5 Pati Tahun Pelajaran 2011/2012, dimana penguasaan materi yang berkaitan dengan materi segiempat hanya 6,74\% (Yoselin, Kartono \&Soedjoko, 2016). Hasil yang sama juga terjadi di Kabupaten Magelang, bahwa daya serap untuk materi pokok geometri selalu berada di bawah $60 \%$ bahkan cenderung selalu menagalami penurunan (Yuliyanto \& Jailani, 2014). Rendahnya kemampuan siswa dalam menyelesaikan soal geometri diduga karena siswa masih menganggap bahwa geometri merupakan pelajaran yang sulit, metode pembelajaran kurang sesuai dengan karakteristik materi geometri yang dipelajari siswa, terbatasnya alat peraga dan bahan ajar geometri berkualitas, kurang tersedianya bahan ajar pengayaan yang layak digunakan, dan siswa cenderung menghafal rumus geometri namun tidak memahami cara untuk menerapkannya Pangesti \& Retnowati, 2017). Selain hal tersebut, rendahnya kemampuan siswa dalam menyelesaikan soal dikarenakan siswa hanya berfokus pada soal yang telah diberikan dan yang dibahas saja tanpa mau untuk berlatih mencoba menyelesaikan soal-soal lain.

Rendahnya prestasi belajar siswa pada matematika tidak dapat lepas dari strategi pembelajaran matematika yang dilakukan guru disekolah (Evianti, 
Jafar, Busnawir \& Masi, 2019). Salah satu taktik yang digunakan guru dalam pembelajaran matematika adalah dengan memberikan contoh-contoh bagaimana memecahkan masalah matematika, tanpa memberikan kesempatan yang banyak pada siswa untuk berusaha menemukan sendiri penyelesaiannya. Dengan taktik mengajar seperti itu, siswa tidak banyak mempunyai inisiatif atau gagasan yang digunakan untuk memecahkan masalah matematika tersebut. Efeknya dari kondisi tersebut adalah siswa seringkali mengalami kesulitan dalam memecahkan masalah matematika, misalnya siswa tidak tahu apa yang perlu mereka kerjakan terlebih dahulu bila menemukan masalah matematika, bahkan dalam menyelesaikan soal ujian, meskipun sebenarnya siswa telah memiliki bekal yang memadai untuk memecahkan masalah tersebut. Selain hal tersebut, faktor yang menyebabkan rendahnya prestasi siswa pada bidang matematika diantaranya adalah ketidakmampuan siswa untuk menyelesaikan soal-soal matematika dan siswa masih melakukan kesalahan-kesalahan dalam menyelesaikan soal matematika (Munawaroh, Rohaeti \& Aripin, 2018).

Mengetahui kesalahan-kesalahan yang dilakukan siswa dalam menyelesaikan soal matematika khususnya geomteri, guru dapat mempersiapkan atau merencanakan pembelajaran yang lebih baik. Untuk mengetahui jenis-jenis kesalahan yang dilakukan oleh siswa dalam menyelesaikan soal-soal matematika maka perlu dilakukan analisis kesalahan siswa (Wahyuni, 2017; Widodo, Turmudi \& Dahlan, 2019; Widodo \& Turmudi, 2017; Yusnia \& Fitriyani, 2010). Dari analisis terhadap kesalahan-kesalahan siswa dapat diketahui terkait jenis-jenis kesalahan yang dilakukan oleh siswa dalam menyelesaikan soal-soal matematika serta dapat diketahui terkait penyebab terjadinya kesalahan siswa dalam menyelesaikan soal-soal matematika (Agustina, Mulyono \& Asikin, 2016; Rahmania \& Rahmawati, 2016; Rofi'ah, Ansori \& Mawaddah, 2019; Satoto, Sutarto \& Pujiastuti, 2013; Sularningsih, Battijanan \& Widodo, 2018). Selain itu dengan melakukan analisis kesalahan siswa dapat membantu guru dalam memberikan tindakan-tindakan yang lebih tepat sehingga dapat dikurangi atau diminimalisir terjadinya kesalahankesalahan siswa yang sama untuk kedepannya serta dapat membantu guru dalam mengevaluasi dan meningkatkan mutu pembelajarannya (Hadiana, Widodo \& Setiana, 2020; Setiawan \& Widodo, 2019).

Berdasarkan uraian tersebut tujuan dalam penelitian ini adalah untuk mengidentifikasi kesalahan yang dilakukan siswa dalame menyelesaikan masalah geomteri berdasarkan teori Newman. Teori Newman iniberkaitan dengan tahapan proses sistematis yang perlu diperhatikan oleh siswa apabila siswa akan memecahkan masalah matematika bentuk soal cerita uraian secara 
ideal sehingga masalah matematika yang berbentuk soal cerita uraian dapat terpecahkan dan tidak terjadi kesalahan-kesalahan. Teori Newmandigunakan karena pada teori ini langkah untuk menyelesaikan masalah terdiri (1) tahapan membaca masalah (reading), (2) tahapan memahami makna suatu permasalahan (comprehension), (3) tahapan transformasi (transformation), (4) tahapan keterampilan proses (process skill) dan (5) tahapan penulisan jawaban akhir (encoding) (Prakitipong \& Nakamura, 2006; Visitasari, Yuli \& Siswono, 2013; Yusnia \& Fitriyani, 2010). Kelima langkah ini relatif lebih mudah diimplementasikan oleh siswa dalam menyelesaikan masalah dan guru mudah untuk melakukan inventarisasi kesalahan yang dilakukan oleh siswa.

\section{Metode}

Desain penelitian dalam penelitian ini adalah deskriptif kualitatif. Dimana pada penelitian ini bertujuan untuk mendeskripsikan kesalahan yang dilakukan oleh siswa. Penelitian ini dilaksanakan di SMP Negeri di Kecamatan Umbulharjo, Yogyakarta. Pada penelitian ini, partisipan penelitian sebanyak 2 siswa kelas VIII A yang diambil secara purposive sampling. Purposive sampling adalah salah stau teknik sampling berdasarkan alasan dantujuandaripeneliti itu sendiri (Creswell, 2012). Alasan yang dijadikan peneliti untuk memilih partisipan penelitian adalah (1) tingkat jawaban siswa dalam memecahkan masalah geometri 3D sangat tinggi, sehingga partisipan penelitian disesuaikan dengan tujuan penelitian yaitu mengetahui kesalahan siswa dalam memecahkan masalah geometri 3D, (2) siswa memiliki komunikasi yang baik, sehingga siswa dapat dengan lancar mengungkapkan perasaan yang ada di dalam pikiran sewaktu melakukan wawancara, (3) rekomendasi yang diberikan oleh guru pengampu matematika kelas VIII SMP Negeri di Kecamatan Umbulharjo, Yogyakarta.

Teknik pengumpulan data dalam penelitian ini yaitu dengan tes dan wawancara. Tes diberikan kepada seluruh siswa kelas VIII A SMP N 10 Yogyakarta. Tes berbentuk uraian yang terdiri dari 5 soal geometri 3D, kelima soal tersebut dapat dilihat pada Gambar 1. 
1. Terdapat sebuah bangunan berbentuk limas segi empat beraturan pada bagian atasnya dan berbentuk kubus pada bagian bawahnya. Diketahui tinggi bangunan tersebut $20,74 \mathrm{~m}$, apabila diketahui panjang bagian bawah bangunan yang berbentuk kubus berukuran $11 \mathrm{~m}$. Hitunglah luas permukaan bangunan tersebut dan hitung panjang diagonal sisi bangunan bagian bawah yang berbentuk kubus!

2. Shely mempunyai 1 lembar karton dengan panjang $62 \mathrm{~cm}$ dan lebar $110 \mathrm{~cm}$. Jika Shely ingin membuat kotak berbentuk balok dengan ukuran panjang $7 \mathrm{~cm}$, lebar $10 \mathrm{~cm}$ dan tinggi $5 \mathrm{~cm}$ menggunakan karton tersebut, berapa jumlah maksimal kotak balok yang dapat dibuat oleh Shely? apakah karton tersisa?

3. Sebuah prisma $A B C D . E F G H$, Bidang $A B F E$ sejajar dan kongruen dengan bidang DCGH. Panjang $\mathrm{AB}=6 \mathrm{~cm}, \mathrm{BC}=11 \mathrm{~cm}, \mathrm{AE}=5 \mathrm{~cm}$ dan $\mathrm{FB}=\sqrt{16} \mathrm{~cm}$. Tentukan luas permukaan prisma ABCD.EFGH!

4. Pak Sadil seorang penjual rubik sedang melakukan pengepakan rubiknya untuk dikirim ke toko pelanggannya. Pak Sadil akan mengepak sejumlah rubiknya (berbentuk kubus) ke dalam kardus berbentuk balok dengan ukuran $80 \mathrm{~cm} \times 40 \mathrm{~cm} \times 64 \mathrm{~cm}$. Berapa maksimal rubik dengan ukuran $8 \mathrm{~cm}$ yang dapat dimuat ke dalam kardus tersebut!

5. Sebuah prisma memiliki alas berbentuk trapesium sama kaki dengan panjang sisi-sisi sejajarnya yaitu $11 \mathrm{~cm}$ dan $19 \mathrm{~cm}$ serta sisi miringnya $5 \mathrm{~cm}$. Jika tinggi prisma tersebut $21 \mathrm{~cm}$, hitunglah volume prisma tersebut!

Gambar 1. Tes Uraian Pada Masalah Geometri 3D

Tes ini telah divalidasi oleh dosen pendidikan matematika dan guru matematika SMP, adapun hasil validasi dapat disimpulkan bahwa instrumen penelitian secara umum sudah baik dan dapat digunakan untuk mengambil data. Wawancaradilakukan kepada 2 siswa yang menjadi partisipasi penelitian. Wawancara kepada partisipan penelitianbertujuan untuk menyakinkan peneliti terkait dengan kesalahan yang dilalkukan oleh siswa dan untuk mengetahui penyebab terjadinya kesalahan siswa dan untuk meyakin. Baik tes dan wawancara dilakukan dengan menggunakan bantuan Whatsapp, hal ini dilakukan karena kondisi sekolah selama pandemi covid-19 melakukan pembelajaran dari rumah.

Dalam penelitian ini peneliti menggunakan teknik analisis datadeskriptif, yaitu dengan mendeskripsikan hasil atau data penelitian yang diperoleh. Adapun tahapan penelitian yang dilakukan secara umum terbagi menjadi tiga tahap yaitu reduksi data, penyajian data dan verifikasi. Prosedur tahapan reduksi data dilakukan dengan (1) mengoreksi hasil pekerjaan siswa sesuai dengan pedoman penyelesaian ideal yang sudah ditetapkan oleh peneliti, (2) memilih siswa yang dijadikan partisipan penelitian sesuai dengan alasan dan tujuan penelitian yang sudah ditetapkan, (3) hasil pekerjaan siswa yang menjadi subjek penelitian kemudian ditransformasikan menjadi bahan untuk wawancara,(4)hasil wawancara disederhanakan menjadi susunan bahasa yang baik dan mengolah hasil wawancara agar menjadi data yang siap 
digunakan. Tahapan penyajian data dilakukan dengan langkah (1) menyajikan analisis hasil pekerjaan siswa dengancaramendeskripsikan jenisjenis kesalahan yang dilakukan berdasarkan teori Newman, (2) menyajikan hasil analisis wawancara dengancara mendeskripsikan garis besar penyebab terjadinya kesalahan siswa. Tahapan verifikasi dilakukan dengan cara menyimpulkan hasil analisis perkejaan siswa dan hasil wawancara siswa sehingga dapat diketahui jenis-jenis kesalahan siswa dan penyebab terjadinya kesalahan siswa

Semua kesalahan yang dilakukan oleh siswa dalam menyelesaikan soal tes tertulis diklasifikasikan berdasarkan 5 jenis kesalahan menurut Newman (Prakitipong \& Nakamura, 2006; Visitasari, Yuli \& Siswono, 2013; Yusnia \& Fitriyani, 2010), yaitu kesalahan membaca, kesalahan memahami makna suatu permasalahan, kesalahan transformasi, kesalahan keterampilan proses, kesalahan penulisan jawaban akhir.

\section{Hasil dan Pembahasan}

Setelah dilakukan tes tertulis dan hasil pekerjaan siswa sudah dikoreksi serta dicek berdasarkan teori Newman dan sudah dinilai berdasarkan pedoman penyelesaian ideal serta penskoran penelitian, kemudian di-ranking dengan kriteria pengelompokkan ranking 1 sampai dengan ranking 11 sebagai kelompok atas, ranking 12 sampai dengan ranking 22 sebagai kelompok sedang, ranking 23 sampai dengan ranking 33 sebagai kelompok bawah dan dipilih serta ditentukan beberapa siswa yang akan menjadi subjek penelitian sekaligus sebagai responden penelitian untuk diwawancarai. Dan terambil 2 siswa yang menjadi subjek penelitian sekaligus sebagai responden penelitian yakni dari kelompok bawah. Kedua partisipan penelitian tersebut selanjutnya disebut dengan S05 dan S11. Karena terlalu banyak hasil jawaban partisipan siswa yang harus ditampilkan, maka hasil pekerjaan siswa hanya ditunjukkan sebagian.

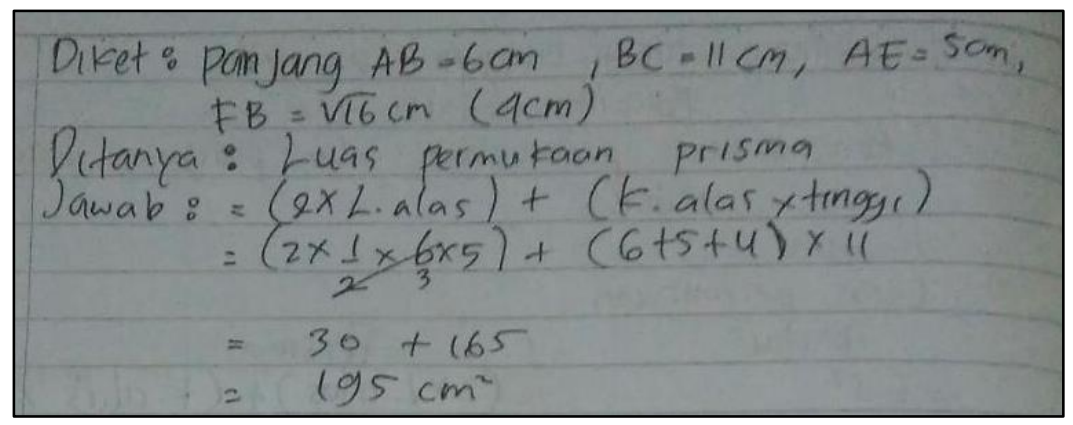

Gambar 2. Hasil jawaban Subyek S05 untuk masalah ketiga 
Sampel hasil pekerjaan siswa dalam menyelesaikan masalaah geometri 3D dapat dilihat pada gambar 2 dan 3.

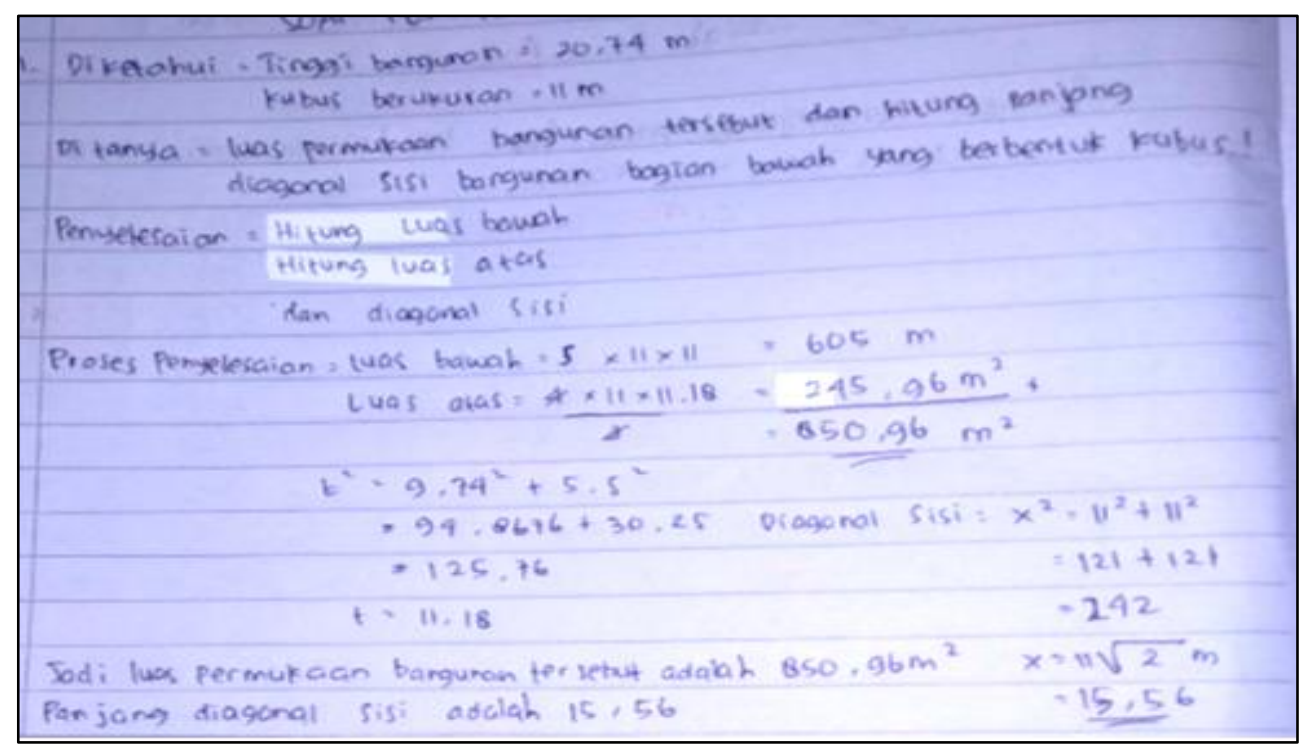

Gambar 3. Hasil jawaban Subyek S11 untuk masalah pertama

Semua kesalahan yang dilakukan oleh siswa dalam menyelesaikan soal tes tertulis diklasifikasikan berdasarkan 5 jenis kesalahan menurut Newmanyaitu kesalahan membaca, kesalahan memahami makna suatu permasalahan, kesalahan transformasi, kesalahan keterampilan proses, kesalahan penulisan jawaban akhir(Prakitipong \& Nakamura, 2006; Visitasari, Yuli \& Siswono, 2013; Yusnia \& Fitriyani, 2010). Adapun indicator setiap jenis kesalahan tersebut diantaranya adalah.

1. Kesalahan Membaca Masalah (Reading Errors): Suatu kesalahan yang dilakukan oleh peserta didik pada saat membaca soal dan terjadi ketika peserta didik tidak mampu membaca kata-kata, lambang maupun simbol yang terdapat dalam soal yang dapat diketahui melalui proses wawancara (Oktavian, 2017; Fatahilah, Wati \&Susanto, 2017).

2. Kesalahan Memahami Makna Suatu Permasalahan (Comprehension Errors): Suatu kesalahan yang dilakukan oleh peserta didik ketika mampu membaca pertanyaan tetapi gagal untuk mendapatkan apa yang dibutuhkan sehingga menyebabkan kegagalan dalam menyelesaikan suatu permasalahan atau telah mampu membaca permasalahan yang ada dalam soal namun tidak mengetahui permasalahan apa yang harus diselesaikan (Filayati, 2019).

3. Kesalahan Transformasi (Transformation Errors): Suatu kesalahan yang dilakukan oleh peserta didik setelah mampu memahami permasalahan yang terdapat dalam soal namun tidak mampu memilih pendekatan untuk 
menyelesaikan permasalahan tersebut atau telah benar memahami pertanyaan dari soal tetapi gagal untuk memilih pendekatan yang tepat untuk menyelesaikan permasalahan tersebut (Amalia, 2017; Satoto, Sutarto \& Pujiastuti, 2013).

4. KesalahanKeterampilan Proses (Process Skill Errors): Suatu kesalahan yang dilakukan oleh peserta didik dalam proses perhitungan setelah mampu memilih pendekatan yang harus dilakukan untuk menyelesaikan permasalahan soal akan tetapi tidak mampu menghitungnya atau telah melakukan operasi yang diperlukan untuk menyelesaikan permasalahan namun tidak dapat menjalankan prosedur dengan benar (Fitriatien, 2019; Amalia, 2017).

5. Kesalahan Penulisan Jawaban Akhir (Encoding Errors): Suatu kesalahan yang dilakukan oleh peserta didik karena kurang telitinya dalam menulis setelah mampu menyelesaikan permasalahan dalam soal tetapi ada sedikit kekurangtelitian yang menyebabkan berubahnya makna jawaban akhir yang ditulis atau telah mampu memecahkan permasalahan dalam soal tetapi salah menuliskan jawaban akhir yang dimaksudkan (Oktaviana, 2017).

Tabel 1 merupakan rekapitulasi jenis-jenis kesalahan yang dilakukan oleh siswa berdasarkan teori Newman dari hasil analisis pekerjaan siswa dan hasil analisis wawancara siswadalam menyelesaikan soal tes tertulis matematika geometri Bangun Ruang Sisi Datar bentuk soal cerita uraian yang diujikan.

Tabel 1. Rekapitulasi Jenis Kesalahan Siswa Berdasarkan Teori Newman

\begin{tabular}{ccc}
\hline $\begin{array}{c}\text { Nomor } \\
\text { Soal }\end{array}$ & $\begin{array}{c}\text { Kode Subjek Penelitian } \\
\text { Sekaligus Sebagai } \\
\text { Responden Penelitian }\end{array}$ & $\begin{array}{c}\text { Jenis-Jenis Kesalahan Yang } \\
\text { Dilakukan Oleh Siswa } \\
\text { Berdasarkan Teori Newman }\end{array}$ \\
\hline 1 & S05, S11 & Transformation Errors \\
& S05, S11 & Process Skill Errors \\
2 & S05, S11 & Encoding Errors \\
& S05, S11 & Comprehension Errors \\
& S05, S11 & Transformation Errors \\
3 & S05, S11 & Process Skill Errors \\
4 & S05, S11 & Encoding Errors \\
& S05, S11 & Process Skill Errors \\
& S05, S11 & Encoding Errors \\
5 & S05, S11 & Transformation Errors \\
& S05 & Process Skill Errors \\
& S05, S11 & Encoding Errors \\
& S05, S11 & Transformation Errors \\
& S05, S11 & Process Skill Errors
\end{tabular}


Berdasarkan Tabel 1, dapat disimpulkan bahwa S05 dan S11 melakukan kesalahan transformation, comprehension, process skill, dan encoding. Hal ini sesuai dengan hasil penelitian sebelumnya yang menyatakan bahwa siswa dalam menyelesaikan masalah matematis melakukan kesalahan transformation, comprehension, process skill, dan encoding (Satoto, Sutarto \&Pujiastuti, 2013; Visitasari, Yuli \& Siswono, 2013; Yusnia \& Fitriyani, 2010).

Kesalahan membaca masalah (reading errors)tidak dilakukan oleh S05 dan S11. Siswa S05 dan S11 dapat membaca soal dengan benar dan mampu membaca kata-kata, lambang maupun simbol yang terdapat dalam soal tanpa adanya kesalahan yang diketahui pada saat proses wawancara. Hal ini sejalan penelitian yang dilakukan oleh Satoto, Sutarto \& Pujiastuti (2013) yang tidak menemukan kesalahan membaca pada siswa siswa kelas X SMA Negeri 1 Kendal. Tetapi bertolak belakang dengan penelitian yang dilakukan oleh Visitasari, Yuli \& Siswono (2013) yang menemukan sekitar 19\% siswa VIII-4 SMPN 1 Sidoarjo yang melakukan kesalahan membaca.

Kesalahan Memahami Makna Suatu Permasalahan (Comprehension Errors) dilakukan subyek S05 dan S11 pada soal kedua. Mereka melakukan kesalahan seperti (a) Tidak lengkap menuliskan permasalahan apa yang harus diselesaikan atau apa yang ditanyakan, dan (b) Salah atau keliru menuliskan permasalahan apa yang harus diselesaikan atau apa yang ditanyakan. Kesalahan ini dilakukan S05 dan S11 pada soal kedua. Kesalahan-kesalahan ini sejalan dengan hasil temuan pada penelitian sebelumnya (Abdullah, Abidin \& Ali, 2015; Hadi, Retnawati, Munadi, Apino \& Wulandari, 2018). Abdullah, Abidin \& Ali (2015) dan Hadi, Retnawati, Munadi, Apino \& Wulandari(2018), menyatakan bahwa sebagian besar kesalahan yang dilakukan oleh siswa dalam menyelesaikan masalah matemtika adalah comprehension error, dampaknya siswa tidak mampu menyelesaikan masalah atau konsep yang digunakan keliru dalam menyelesaikan masalah.

Kesalahan tranformasi yang terjadi pada subyek S05 dan S11 pada sebagian besar soal geometri. Hal ini seperti temuan yang telah dilakukan oleh Prakitipong \& Nakamura (2006) dan Yusnia \& Fitriyani (2010) menyatakan bahwa kesalahan transformasi dapat terjadi apabila siswa salah memilih langkah atau metode beserta cara yang seharusnya digunakan, tidak mampu memilih langkah atau metode beserta cara yang seharusnya digunakan, salah memilih langkah atau metode beserta rumus yang seharusnya digunakan, dan tidak mampu memilih langkah atau metode beserta rumus yang seharusnya digunakan. 
Kesalahan ketrampilan proses yang pada subyek S05 dan S11 pada semua semua masalah geometri. Subyek tidak menuliskan satuan, simbol tidak dituliskan dan salah dalam melakukan operasi hitung. Begitu juga pada kesalahan penulisan jawaban akhir, subyek S05 dan S11 juga terjadi pada semua soal geometri. Kedua kesalahan ini sejalan dengan hasil penelitian yang dilakukan sebelumnya yang menemukan bahwa sebagian besar siswa tidak melakukan kesalahan proses dan kesalahan tidak menuliskan jawaban akhir (Abdullah, Abidi \& Ali, 2015; Zakaria, Ibrahim \& Maat, 2010; Hadi, Retnawati, Munadi, Apino \& Wulandari, 2018). Abdullah, Abidin \& Ali, 2018; Prakitipong \& Nakamura, 2006; Satoto, Sutarto \& Pujiastuti, 2013; Visitasari, Yuli, \& Siswono, 2013; Yusnia \& Fitriyani, 2010).

Untuk mengetahui, penyebab terjadinya kesalahan siswa dalam menyelesaikan masalah, peneliti melakukan wawancara secara virtual menggunakan media whatsapp. Dari hasil wawancara disimpulkan bahwa (1) penyebab terjadinya kesalahan memahami makna suatu permasalahan (comprehension errors) adalah tidak teliti menentukan hal yang ditanyakan soal dan keliru menafsirkan hal yang ditanyakan soal. (2) Penyebab terjadinya kesalahan transformasi (transformation errors) adalah akibat kesalahan sebelumnya, tidak fokus menuliskan langkah atau metode, tidak paham langkah atau metode yang seharusnya digunakan, tidak paham penerapan teorema phytagoras, bingung menggunakan rumus yang seharusnya digunakan, buru-buru dalam menuliskan langkah atau metode, tidak menggunakan langkah atau metode yang seharusnya digunakan, lupa rumus yang seharusnya digunakan, tidak teliti dalam menuliskan rumus yang seharusnya digunakan, bingung dalam memilih langkah atau metode yang seharusnya digunakan, tidak menuliskan langkah atau metode beserta cara yang seharusnya digunakan dan tidak menuliskan langkah atau metode beserta rumus yang seharusnya digunakan.

Penyebab terjadinya kesalahan keterampilan proses (process skill errors) adalah akibat kesalahan sebelumnya, menuliskan satuan yang tidak sesuai, tidak menuliskan lambang simbol penting pada proses perhitungan, tidak teliti dalam melakukan proses perhitungan, buru-buru dalam melakukan proses perhitungan dan tidak fokus dalam melakukan proses perhitungan. Selain itu, penyebab terjadinya kesalahan penulisan jawaban akhir (encoding errors) S05 dan S11 adalah akibat kesalahan sebelumnya, tidak menuliskan satuan, tidak teliti dalam menuliskan jawaban akhir dan keliru menafsirkan hal yang ditanyakan soal. 


\section{Simpulan}

Kesalahan yang dilakukan oleh partisipan penelitian dalam menyelesaikan soal matematika geometri Bangun Ruang adalah (1) kesalahan memahami makna suatu permasalahan (comprehension errors); (2) kesalahan transformasi (transformation errors); (3) kesalahan keterampilan proses (process skill errors); (4) kesalahan penulisan jawaban akhir (encoding errors). Penyebab terjadinya kesalahan tersebut seperti keliru menafsirkan hal yang ditanyakan, tidak memahami konsep geometri. Berkaitan dengan identifikasi kesalahan yang dilakukan siswa dalam menyelesaikan masalah geometri 3D, diperoleh gambaran kesalahan-kesalahan siswa dan penyebabnya. Dengan mengidentifikasi kesalahan tersebut, guru terbantu dalam merencanakan pembelajaran yang tepat sehingga dapat mengantisipasi kesalahan yang sering dilakukan oleh siswa.

\section{Ucapan Terima Kasih}

Penulis menyadari bahwa dalam penelitian ini tidak terlepas dari dukungan, arahan, bimbingan, bantuan serta motivasi dari berbagai pihak. Untuk itu penulis ingin mengucapkan terimakasih kepada Krida Singgih Kuncoro, M.Pd yang telah memvalidasi tes tertulis materi geometri. Serta kami mengucapkan terima kasih kepada SMP N 10 Yogyakarta yang telah memberikan kesempatan untuk melakukan penelitian.

\section{Daftar Pustaka}

Abdullah, A. H., Abidin, N. L. Z., \& Ali, M. (2015). Analysis of students' errors in solving Higher Order Thinking Skills (HOTS) problems for the topic of fraction. Asian Social Science, 11(21), 996-1005. https://doi.org/10.5539/ass.v11n21p133

Agustina, I. R., Mulyono, \& Asikin, M. (2016). Analisis Kesalahan Siswa Kelas VIII Dalam Menyelesaikan Soal Matematika Bentuk Uraian Berdasarkan Taksonomi Solo. UNNES Journal of Mathematics Education, 5(2), 92-100.

Amalia, S. R. (2017). Analisis Kesalahan Berdasarkan Prosedur Newman dalam Menyelesaikan Soal Cerita Ditinjau dari Gaya Kognitif Mahasiswa. AKSIOMA: Jurnal Matematika dan Pendidikan Matematika, 8(1), 17-30.

Creswell, J. W. (2012). Research Design Qualitative,Quantitative, and Mixed Second Edition. New York: Sage Pub.

Evianti, N., Jafar, J., Busnawir, B., \& Masi, L. (2019). Analisis Kesalahan Siswa Kelas IX MTs Negeri 2 Kendari Dalam Menyelesaikan Soal-Soal Lingkaran. Jurnal Pendidikan Matematika, 10(2), 138-149. https://doi.org/10.36709/jpm.v10i2.7247

Fatahillah, A., Wati, Y. F., \& Susanto, S. (2017). Analisis Kesalahan Siswa Dalam Menyelesaikan Soal Cerita Matematika Berdasarkan Tahapan Newman Beserta Bentuk Scaffolding Yang Diberikan. Kadikma, 8(1), 40-51.

Filayati, U. U. (2019). Analisis Kesalahan Siswa Dalam Memecahkan Soal Cerita Pada Materi Limas Ditinjau Dari Gaya Belajar. Jurnal Inovasi Pembelajaran Matematika, 1(1), 1-10.

Fitriatien, S. R. (2019). Analisis Kesalahan Dalam Menyelesaikan Soal Cerita Matematika Berdasarkan Newman. Jurnal Ilmiah Pendidikan Matematika, 4(1), 53-64.

Fuadi, R., Johar, R., \& Munzir, S. (2016). Peningkatkan Kemampuan Pemahaman dan 
Penalaran Matematis melalui Pendekatan Kontekstual. Jurnal Didaktik Matematika, 3(1), 47-54. https://doi.org/10.24815/jdm.v3i1.4305

Hadi, S., Retnawati, H., Munadi, S., Apino, E., \& Wulandari, N. F. (2018). The difficulties of high school students in solving higher-order thinking skills problems. Problems of Education in the 21st Century, 76(4), 520-532.

Hadiana, M. R., Widodo, S. A., \& Setiana, D. S. (2020). Analisis Kesalahan Dalam Menyelesaikan Masalah Segiempat Ditinjau Dari Perkembangan Kognitif. Journal of Honai Math, 3(1), 1-12. https://doi.org/10.30862/jhm.v3i1.82

Johar, R. (2012). Domain Soal PISA untuk Literasi Matematika. Jurnal Peluang, 1(1), 30-41.

Kartianom, K., \& Retnawati, H. (2018). Why Are Their Mathematical Learning Achievements Different? Re-Analysis TIMSS 2015 Data in Indonesia, Japan And Turkey. International Journal on New Trends in Education and Their Implications, 9(2), 33-46.

Kaune, C., Cohors-Fresenborg, E., \& Nowinska, E. (2014). Development of Metacognitive and Discursive Activities in Indonesian Maths Teaching: A Theory Based Design and Test of a Learning Environment. Indonesian Mathematical Society Journal on Mathematics Education, 2(1), 15-40.

Mansur, N. (2018). Melatih Literasi Matematika Siswa dengan Soal PISA. Prisma Prosiding Seminar Nasional Matematika, 140-144.

Maskar, S. (2018). Alternatif Penyusunan Materi Ekspresi Aljabar Untuk Siswa SMP/MTs Dengan Pendekatan Pendidikan. Prisma, VII(1), 53-69.

Morse, S., \& Morse, S. (2019). Human Development Index. In The Rise and Rise of Indicators: Their History and Geography. Routledge. https://doi.org/10.4324/9781315226675-3

Mullis, I. V. ., Martin, M. O., Foy, P., \& Hooper, M. (2018). TIMSS. In TIMSS 2015 International Result in Mathematics. IEA. https://doi.org/10.4135/9781506326139.n704

Mullis, I. V. S., Martin, M. O., Foy, P., \& Drucker, K. T. (2012). PIRLS 2011 International Results in Reading. In TIMSS \& PIRLS International Study Center. https://doi.org/10.1097/01.tp.0000399132.51747.71

Mullis, I. V. S., Martin, M. O., Foy, P., \& Hooper, M. (2015). TIMSS 2015 International Results in Mathematics. In IEA. TIMSS \& PIRLS.

Munawaroh, N., Rohaeti, E. E., \& Aripin, U. (2018). Analisis Kesalahan Siswa Berdasarkan Kategori Kesalahan Menurut Watson dalam Menyelesaikan Soal Komunikasi Matematis Siwa SMP. JPMI (Jurnal Pembelajaran Matematika Inovatif), 1(5), 993-1004. https://doi.org/10.22460/jpmi.v1i5.p993-1004

Nurani, A., \& Ramadhani, N. (2014). Perancangan Buku Interaktif Jarimatika Penjumlahan dan Pengurangan sebagai Alternatif Pembelajaran Matematika untuk Anak Usia 5-7 Tahun. Jurnal Sains Dan Seni Pomits, 3(1), F-13-F17. https://doi.org/10.12962/j23373520.v3i1.6030

OECD. (2019). PISA 2018 insights and interpretations. OECD Publishing.

Oktaviana, D. (2017). Analisis tipe kesalahan berdasarkan teori Newman dalam menyelesaikan soal cerita pada mata kuliah matematika diskrit. Edu Sains: Jurnal Pendidikan Sains dan Matematika, 5(2), 22-32.

Pangesti, F. T. P., \& Retnowati, E. (2017). Pengembangan bahan ajar geometri SMP berbasis cognitive load theory berorientasi pada prestasi belajar siswa. PYTHAGORAS: Jurnal Pendidikan Matematika, 2(1), 33-46. https://doi.org/10.21831/pg.v12i1.14055

Prakitipong, N., \& Nakamura, S. (2006). Analysis of Mathematics Performance of Grade Five Students in Thailand Using Newman Procedure. Journal of International Cooperation in Education, 9(1), 111-122.

Rahmania, L., \& Rahmawati, A. (2016). Analisis Kesalahan Siswa Dalam Menyelesaikan Soal Cerita. Jurnal Matematika Dan Pendidikan Matematika, 1(2), 165-174.

Rahmawati, L. N., Pitadjeng, Nugraheni, N. (2013). Peningkatan Kualitas Pembelajaran 
Geometri Melalui Kepala Bernomor Terstruktur Berbantuan Media Audio Visual. Joyful Learning Journal, 2(2), hal 10-17.

Rofi'ah, N., Ansori, H., \& Mawaddah, S. (2019). Analisis Kesalahan Siswa Dalam Menyelesaikan Soal Cerita Matematika Berdasarkan Langkah Penyelesaian Polya. EDUMAT: Jurnal Pendidikan Matematika, 7(2), 120. https://doi.org/10.20527/edumat.v7i2.7379

Satoto, S., Sutarto, H., \& Pujiastuti, E. (2013). Analisis Kesalahan Hasil Belajar Siswa Dalam Menyelesaikan Soal Dengan Prosedur Newman. Unnes Journal of Mathematics Education Research, 2(1), 76-83.

Sellar, S., \& Lingard, B. (2014). The OECD and the expansion of PISA: New global modes of governance in education. British Educational Research Journal, 40(6), 917-936. https://doi.org/10.1002/berj.3120

Setiawan, D. I., \& Widodo, S. A. (2019). Analisis Kesalahan dalam Menyelesaikan Masalah Segi empat Ditinjau dari Perkembangan Kognitif. Jurnal Edukasi Matematika Dan Sains, 7(2), 45-54. https://doi.org/10.25273/jems.v7i2.5291

Setiawan, H., Dafik, D., Lestari, N. D. S. (2014). Soal Matematika Dalam Pisa Kaitannya Dengan Literasi Matematika Dan Keterampilan Berpikir Tingkat Tinggi. Prosiding Seminar Nasional Matematika, hal: 244-251.

Sholihah, D. A., \& Mahmudi, A. (2015). Keefektifan Experiential Learning Pembelajaran Matematika MTs Materi Bangun Ruang Sisi Datar. Jurnal Riset Pendidikan Matematika, 2(2), 175-185. https://doi.org/10.21831/jrpm.v2i2.7332

Siagian, M. D. (2016). Kemampuan koneksi matematik dalam pembelajaran matematika. MES: Journal of Matematics Education and Science, 2(1), 58-67

Sofiah, R., Suhartono, S., \& Hidayah, R. (2020). Analisis Karakteristik Sains Teknologi Masyarakat (STM) Sebagai Model Pembelajaran: Sebuah Studi Literatur. Pedagogi: Jurnal Penelitian Pendidikan, 7(1), 1-18.

Sularningsih, S., Battijanan, A., \& Widodo, S. A. (2018). Analisis Kesalahan Dalam Menyelesaikan Masalah Matematika Dengan Menggunakan Langkah Poliya Siswa SMK. Prosiding Seminar Nasional Etnomatnesia. hal: 754-759.

Sutrimo, S., Kamid, K., \& Saharudin, S. (2019). LKPD Bermuatan Inquiry dan Budaya Jambi: Efektivitas dalam Meningkatkan Kemampuan Berpikir Kreatif Matematis. IndoMath: Indonesia Mathematics Education, 2(1), 29-36. https://doi.org/10.30738/indomath.v2i1.3841

Utami, F. D., Djatmika, E. T., \& Sa'dijah, C. (2017). Kemampuan Pemecahan Masalah Matematis Siswa Kelas IV SDN Blimbing 01. Seminar Nasional Teknologi Pembelajaran Dan Pendidikan Dasar 2017. hal: 673-683

Visitasari, R., Yuli, T., \& Siswono, E. (2013). Kemampuan Siswa Memecahkan Masalah Berbentuk Soal Cerita Aljabar Menggunakan Tahapan Analisis Newman. MathEdunesa, 2(2), 1-8.

Wahyuni, A. (2017). Analisis Hambatan Belajar Mahasiswa Pada Mata Kuliah Kalkulus Dasar. JNPM (Jurnal Nasional Pendidikan Matematika), 1(1), 10-23. https://doi.org/10.33603/jnpm.v1i1.253

Watts, A. (2015). International surveys: PISA, TIMSS, PIRLS. Cambridge International Examinations.

Widodo, S. A. (2013). Implementasi Team Teaching Terhadap Prestasi Belajar Siswa SMA Kelas X Se-Kota Yogyakarta Pada Materi Trigonometri. Union: Jurnal Pendidikan MAtematika, 1(1), 43-50.

Widodo, S. A., \& Turmudi. (2017). Guardian Student Thinking Process in Resolving Issues Divergence. Journal of Education and Learning, 11(4), 431-437. https://doi.org/10.11591/edulearn.v11i4.5639

Widodo, S. A., Turmudi, T., \& Dahlan, J. A. (2019). An Error Students In Mathematical Problems Solves Based On Cognitive Development. International Journal Of Scientific $\mathcal{E}$ 
Technology Research, 8(07), 433-439.

Yoselin, K., Kartono, K., \&Soedjoko, E. (2016). Komparasi Pembelajaran Matematika Dengan Model Jigsaw Dan GI Pada Pencapaian Kemampuan Pemecahan Masalah. Unnes Journal of Mathematics Education., 4(1), 33-39. https://doi.org/10.15294/ujme.v5i1.9346

Yuliyanto, Y., \& Jailani, J. (2014). Pengembangan Perangkat Pembelajaran Geometri SMP Menggunakan Metode Penemuan Terbimbing Pada Kelas VIII Semester II. Jurnal Riset Pendidikan Matematika, 1(1), 127-138. https://doi.org/10.21831/jrpm.v1i1.2670

Yusnia, D., \& Fitriyani, H. (2010). Identifikasi Kesalahan Siswa Menggunakan Newman's Error Analysis (NEA) pada Pemecahan Masalah Operasi Hitung Bentuk Aljabar. Seminar Nasional Pendidikan, Sains Dan Teknologi Fakultas Matematika Dan Ilmu Pengetahuan Alam Universitas Muhammadiyah Semarang. Hal: 78-83

Zakaria, E., Ibrahim, \& Maat, S. M. (2010). Analysis of students' error in learning of quadratic equations. International Education Studies, 3(3), 105-110.

Zulkardi. (2002). Developing A Learning Environment On Realistic Mathematics Education For Indonesian Student Teachers. University of Twente. 